\title{
Awareness of indoor pollution in rural and urban houses of Ludhiana district
}

\author{
D. KAUR, M. SIDHU, S. BAL AND P. SANDHU
}

Received: 06.01.2015; Revised: 02.04.2015; Accepted: 17.04.2015

See end of the paper for authors' affiliations

\section{S. BAL}

Department of Family Resource Management, College of Home Science, Punjab Agricultural University, LUDHIANA (PUNJAB) INDIA

Email : balsharanbir@pau.edu me
ABSTRACT : Living in a technologically developing society, our lifestyle and attitude have become self-oriented which has added to the menace of household pollution. Environmental awareness is needed to change the mindset of modern society and needs to provide some alternatives which can help the women to save the environment, children, family and society. There is a need to make the public aware about environment, the serious health hazards of environmental pollution and their rights to live in a clean and healthy environment. Study conducted on the awareness of rural and urban homemakers revealed that majority of the rural and urban respondents were aware of different causes of indoor pollution though the awareness was more in urban homemakers. Among the awareness of environmental causes maximum awareness was found to be 'dust in abundance' with mean score 2.73 , followed by high humidity inside (2.63). Major chemical based factors reported was awareness of 'leaking gas pipes or gas cylinder' with mean score 2.68. Majority of the selected respondents $(55.83 \%)$ were aware of the indoor pollution due to chocked pipes under the category of constructional faults and household articles. Damp and soiled bedding were placed at rank one with mean score 2.75. Other pollution creating causes categorized under 'miscellaneous causes' were: stagnated water, fungus and black mould, pet waste, animal dander, cockroaches, lizards, insects and spider's webs. Awareness of stagnated water was considered as one of the most polluting cause by 75.00 per cent respondents.

KEY WORDS: Chemical causes, Constructional causes, Environmental awareness

- HOW TO CITE THIS PAPER : Kaur, D., Sidhu, M., Bal, S. and Sandhu, P. (2015). Awareness of indoor pollution in rural and urban houses of Ludhiana district. Asian J. Home Sci., 10 (1) : 102-107. 